\title{
PENDAFTARAN JAMINAN FIDUSIA SEBAGAI PEMENUHAN ASAS PUBLISITAS
}

\author{
Supianto ${ }^{1}$, Nanang Tri Budiman ${ }^{2}$ \\ Fakultas Hukum Universitas Islam Jember \\ Jl. Kyai Mojo No.101, Kaliwates Kidul, Kaliwates, Kec. Kaliwates, Kabupaten \\ Jember, Jawa Timur 68133, Indonesia \\ supianto@uij.ac.id \\ DOI: https://doi.org/10.35719/ijl.v1i3.84
}

\begin{abstract}
Before the birth of the Fiduciary Guarantee Law (UUJF), the issue of fiduciary security registration was not an obligation, but with the birth of the UUJF, registration of fiduciary guarantees was a very crucial stage and had an impact on many aspects of the following law. Such explanation is also recognized in the General Elucidation of UUJF that one of the reasons fiduciary guarantees does not provide legal certainty, especially to fiduciary recipients, one of which is because the fiduciary guarantee is not registered. The fulfillment of the principle of publicity in fiduciary security is carried out by registering fiduciary security at the Fiduciary Registration Office. Regarding the request, the registration office will record the guarantee in the Fiduciary Register Book and will issue a Fiduciary Guarantee Certificate which has the order for Justice Based on Almighty God. The normalization of fiduciary security registration in UUJF is a legal norm that is compelling (dwingend recht). This can be seen through two aspects, namely the use of the word mandatory in UUJF as a command norm, and from the aspect of the legal principle of objects which are closed, so that the norm cannot be deviated. With regard to fiduciary security that is not registered, the creditor as the recipient of fiduciary does not receive the rights and benefits specified in the UUJF, including material rights, priority rights, executive rights, and application of criminal provisions. Keywords : Registration, Fiduciary Guarantee, Publicity Principle.
\end{abstract}

Abstrak : Sebelum lahirnya Undang-Undang Jaminan Fidusia (UUJF), persoalan pendaftaran jaminan fidusia bukanlah menjadi sebuah

\section{IJLIL: INDONESIAN JOURNAL OF LAW AND ISLAMIC LAW VOLUME 2 NOMOR 2 JULI-DESEMBER 2020; \\ ISSN 2721-5261 E-ISSN 2775-460X}


kewajiban, namun dengan lahirnya UUJF, pendaftaran jaminan fidusia merupakan tahapan yang sangat krusial dan berdampak pada banyak aspek hukum selanjutnya. Penjelasan demikian juga diakui dalam Penjelasan Umum UUJF bahwa salah satu sebab jaminan fidusia tidak memberikan kepastian hukum terutama kepada penerima fidusia, salah satunya adalah karena jaminan fidusia tersebut tidak didaftarkan. Pemenuhan asas publisitas dalam jaminan fidusia dilakukan melalui pendaftaran jaminan fidusia ke Kantor Pendaftaran Fidusia. Terhadap permohonan tersebut, kantor pendaftaran akan mencatat jaminan tersebut dalam Buku Daftar Fidusia dan akan menerbitkan Sertifikat Jaminan Fidusia yang mempunyai irah-irah Demi Keadilan Berdasarkan Ketuhanan Yang Maha Esa. Penormaan pendaftaran jaminan fidusia dalam UUJF merupakan norma hukum yang bersifat memaksa (dwingend recht). Hal ini dapat dilihat melalui dua aspek yaitu adanya penggunaan kata wajib dalam UUJF merupakan norma perintah, dan dari aspek asas hukum benda yang bersifat tertutup, sehingga norma tersebut tidak dapat disimpangi. Terhadap jaminan fidusia tidak didaftarkan maka kreditor sebagai pihak penerima fidusia tidak memperoleh hak-hak serta keuntungan-keuntungan yang sudah ditentukan dalam UUJF, antara lain Hak kebendaan, hak yang didahulukan (preferen), hak eksekutorial, dan penerapan ketentuan pidana.

Kata Kunci : Pendaftaran, Jaminan Fidusia, Asas Publisitas

\section{Pendahuluan}

Hukum jaminan merupakan bidang hukum yang tergolong kedalam kelompok hukum ekonomi (the economic law), ${ }^{1}$ yang memiliki fungsi sebagai pendukung dalam kegiatan perekonomian dan pembangunan secara umum. Penyediaan benda obyek jaminan dalam perjanjian jaminan kebendaan merupakan kepentingan dan keuntungan kreditor tertentu yang telah memintanya, sehingga memberikan hak

\footnotetext{
${ }^{1}$ Sri Soedewi Maschoen Sofwan, Hukum Jaminan Di Indonesia, Pokok-pokok Hukum Jaminan dan Jaminan Perorangan, (Yogyakarta: Liberti, 1980), 33.
} 
atau kedudukan istimewa bagi kreditor tersebut. Jaminan kebendaan dilakukan dengan cara membebani suatu benda tertentu dengan lembaga jaminan tertentu sehingga apabila debitor tidak melunasi utangnya kepada kreditor, maka kreditor dapat menuntut pelunasan piutangnya dari hasil penjualan didepan umum atas benda tertentu tersebut. Adanya jaminan terutama jaminan yang bersifat kebendaan menjadi sangat penting untuk memberikan kepastian terkait dengan keyakinan akan terpenuhinya pengembalian pinjaman yang sudah dikucurkan kepada debitur.

Menurut sifatnya, terdapat dua macam jaminan yaitu jaminan yang bersifat umum dan yang bersifat khusus. ${ }^{2}$ Jaminan yang bersifat umum adalah jaminan yang diberikan untuk semua kreditor dan menyangkut semua harta yang dimiliki debitor, hal ini sesuai Pasal 1131 KUH Perdata. Sedangkan untuk jaminan yang bersifat khusus adalah jaminan yang diberikan oleh debitor dalam bentuk penunjukan dan/atau penyerahan benda tertentu yang dilakukan secara khusus. Benda jaminan tersebut diberikan sebagai suatu jaminan agar telunasinya hutang debitor kepada kreditor. Jaminan yang khusus ini merubah kedudukan kreditor menjadi kreditor diutamakan (preferen), artinya bahwa bila pihak debitor lalai memenuhi kewajibannya, maka kreditor tersebut mempunyai hak untuk menjual benda

\footnotetext{
${ }^{2}$ Gunawan widjaja dan Ahmad Yani, Jaminan Fidusia, Jakarta : Rajagrafindo Persada, 2000), 79
} 
jaminan tersebut untuk melunasi hutangnya tanpa ada kewajiban memperhatikan kepentingan kreditor lainnya.

Jenis lembaga pengikatan jaminan kebendaan di Indonesia sampai saat ini adalah Gadai, Hipotik, Hak Tanggungan dan Fidusia. Pada awalnya, lembaga jaminan yang objeknya hak atas tanah adalah hipotik dan creditverband. ${ }^{3}$ Namun perubahan terjadi setelah terbitnya Undang-Undang No. 5 Tahun 1960 tentang Peraturan Dasar Pokok-pokok Agraria (UUPA) yang telah mengamanatkan untuk pembentukan peraturan yang mengatur tentang hak tanggungan. Amanat UUPA tersebut baru dapat terealisasi setelah diundangkannya UU No. 4 Tahun 1996 Tentang Hak Tanggungan (UUHT). Selain Hak Tanggungan, hak-hak jaminan yang banyak dimanfaatkan saat ini adalah Gadai (pand), Hipotek selain tanah dan Jaminan Fidusia. Lahirnya Jaminan Fidusia dengan diundangkan dalam UU Nomor 42 Tahun 1999 Tentang Jaminan Fidusia dinilai oleh para ahli merupakan lembaga jaminan sebagai perluasan dari Lembaga gadai (pand).

Pengaturan tentang Jaminan Fidusia tidak ditemukan dalam KUHPerdata. Sebelum lahirnya UUJF, pengaturan fidusia masih berdasar pada Yurisprudensi. Pengaturan mengenai jaminan kebendaan dalam KUHPerdata hanya mengatur tentang lembaga gadai dan hipotek, hal ini

\footnotetext{
${ }^{3}$ Herowati, Poesoko, Parate Executie Obyek Hak Tanggungan, (Yogyakarta : Laksbang, 2008), 3
} 
merupakan sebuah konsekuensi dari adanya pembagian benda bergerak dan tidak bergerak. ${ }^{4}$ Lembaga Gadai digunakan untuk jaminan dengan objek benda bergerak dan hipotek untuk objek benda tidak bergerak. Dalam perkembangan selanjutnya, Lembaga Gadai dinilai banyak memiliki kekurangan dalam memenuhi perkembangan kebutuhan dalam masyarakat. ${ }^{5}$ Penggunaan jaminan fidusia didalam praktek kegiatan pinjam-meminjam memang lebih disukai, hal ini karena prosedurnya pelaksanaannya yang mudah, cepat dan murah. Selain itu, jaminan Fidusia juga dapat dipergunakan untuk penjaminan terhadap hak atas tanah yang tidak dapat dibebani hak tanggungan, sebagai pengganti posisi kreditverban. ${ }^{6}$

Asas-asas umum dalam hukum jaminan kebendaan adalah bersifat mutlak atau absolut, selalu mengikuti bendanya (droit de suite), preferen, spesialitas dan publisitas. Asas publisitas atau keterbukaan ditujukan agar pihak ketiga atau pihak lain yang memiliki kepentingan tertentu terhadap benda sebagai objek jaminan dapat mengetahui terkait adanya pembebanan jaminan atas benda tersebut. Cara yang memungkinkan agar pihak-pihak yang berkepentingan

\footnotetext{
${ }^{4}$ Moch. Isnaeni, Hipotek Pesawat Udara di Indonesia, (Surabaya : CV. Dharma Muda, 1996), 35

${ }^{5}$ Salim HS, Perkembangan Hukum Jaminan Di Indonesia, (Jakarta : PT. Raja Grafindo Persada, 2004), 57

${ }^{6}$ Djuhaendah Hasan, Lembaga Jaminan Kebendaan bagi Tanah dan Benda lain yang Melekat pada Tanah dalam Konsepsi Penerapan Asas Pemisahan Horisontal, (Bandung : PT. Citra Aditya Bakti, 1996), 365
} 
tentang adanya pembebanan jaminan terhadap benda tersebut adalah dengan proses pencatatan dan pendaftaran pada Lembaga tertentu yang bersifat terbuka untuk umum. Pendaftaran atau pencatatan adanya suatu jaminan bertujuan agar dapat memberikan kepastian hukum kepada pihak yang memiliki kepentingan juga untuk memberikan hak yang didahulukan (preferen) kepada kreditur terhadap krediturkreditur lain. Pemenuhan asas publisitas ini dalam UndangUndang Nomor 42 Tahun 1999 Tentang Jaminan Fidusia (UUJF) tertuang dalam Pasal 11 ayat (1) yang mewajibkan benda yang dibebani jaminan fidusia untuk didaftarkan.

Dalam paraktik di masyarakat, tidak semua perjanjian utang-piutang atau perjanjian kredit yang menggunakan pembebanan jaminan tidak didaftarkan ke Kantor Pendaftaran Fidusia. ${ }^{7}$ Alasan-alasan yang dikemukakan adalah terkait dengan besarnya biaya dalam proses pembuatan akta di notaris yang jumlahnya melebihi dari aturan yang ditetapkan $^{8}$ serta prosedur pendaftaran dirasakan memerlukan waktu yang lama. ${ }^{9}$

Terkait dengan pendaftaran jaminan fidusia untuk memenuhi asas publisitas dalam hukum jaminan kebendaan

\footnotetext{
${ }^{7}$ Tan Kamelo, Hukum Jaminan Fidusia Suatu Kebutuhan yang Didambakan, (Bandung : Alumni, 2006), 213

8 Notaris memungut biaya pembuatan akta jaminan fidusia sebesar $2 \%$ dari nilai jaminan, Andi Prajitno, Hukum Fidusia-Problematika Yuridis Pemberlakuan UU No. 42 Tahun 1999, (Malang : Bayumedia, 2011), 191

9 Andi Prajitno, Hukum Fidusia-Problematika Yuridis Pemberlakuan UU No. 42 Tahun 1999, 215
} 
diatas, yang akan ditelaah dalam penulisan ini adalah apakah pendaftaran jaminan fidusia merupakan suatu kewajiban yang imperative ataukah hanya merupakan pilihan yang tidak mengikat.

\section{Pembahasan}

\section{Sistem Pendaftaran dalam Jaminan Kebendaan}

Pada dasarnya suatu kegiatan pencatatan dan pendaftaran bertujuan untuk melindungi hak dan kepentingan dari pihak-pihak yang melakukan suatu perbuatan hukum, terhadap adanya kemungkinan terjadinya pelanggaran dilakukan oleh pihak lain. Sebaliknya, adanya kepentingan dari pihak ketiga yang memiliki beritikad baik terkait hubungan dengan benda yang menjadi obyek perbuatan hukum para pihak, maka diperkenalkan sistem publikasi didalam aturan hukum. Kegiatan pencatatan dan pendaftaran dalam hukum perorangan dilakukan oleh Negara bertujuan semata-mata untuk kepentingan setiap orang yang ada dalam masyarakat.

Dalam bidang hukum kebendaan, pencatatan dan pendaftaran merupakan hak dari para pihak dan hanya dilakukan jika hal tersebut dikehendaki oleh para pihak itu sendiri. Pendaftaran tersebut dilakukan oleh para pihak apabila dianggap perlu agar hubungan hukum mereka ingin diketahui oleh pihak lain demi untuk melindungi hak-hak 
mereka. Sedangkan didalam bidang hukum perjanjian, pencatatan dan pendaftaran sama sekali tidak dipersyaratkan. ${ }^{10}$

Tahap pendaftaran merupakan suatu hal yang sangat penting dalam bidang hukum kebendaan. Pelaksanaan pendaftaran diserahkan kepada kehendak para pihak yang melangsungkan suatu hubungan hukum tersebut. Pendaftaran dan publikasi ditujukan untuk melindungi kepentingan pihak ketiga, sehingga pihak ketiga yang ingin mengetahui adanya suatu perbuatan hukum tertentu atas kebendaan tertentu, dapat dengan mudah untuk melakukan pemeriksaan melalui publikasi yang bersifat terbuka untuk umum tersebut. Apabila pendaftaran dan publikasi tidak dilakukan, maka akan mengakibatkan perbuatan hukum tersebut tidak dapat mengikat terhadap pihak ketiga.

Lembaga pendaftaran pertama kali dikenal di Mesir kemudian berkembang ke Negara-negara barat, seperti Perancis tahun 1790 dan Nederland tahun 1811. ${ }^{11}$ Hukum Romawi telah mampu memilah-milah sistem pencatatan dan publikasi untuk masing-masing jenis hukum, antara lain hukum perorangan, hukum kebendaan dan hukum perjanjian. ${ }^{12}$ Pendaftaran yang dimaksud disini berasal dari

\footnotetext{
${ }^{10}$ Kartini Mulyadi dan Gunawan Widjaja, Seri Hukum Harta Kekayaan-Kebendaan pada Umumnya, Prenada Media, Jakarta, 2003, hal.65

${ }^{11}$ Herowati, Poesoko, Parate Executie Obyek Hak Tanggungan, 101

${ }^{12}$ Kartini Mulyadi dan Gunawan Widjaja, Seri Hukum Harta Kekayaan-Kebendaan pada Umumnya, 64
} 
kata cadastre yang berasal dari bahasa Latin, capitastrum yang berarti suatu capita atau unit atau register yang dibuat untuk keperluan perpajakan bagi tanah-tanah Romawi. Pada awalnya pendaftaran ini dilakukan untuk kepentingan fiskal, dalam perkembangan selanjutnya, kadaster atau pendaftaran tersebut tidak hanya untuk kepentingan fiskal saja yang lebih bersifat administratif, namun kemudian berkembang bagi aspek-aspek keperdataan mengenai kepastian hak-hak atas tanah tersebut. Dengan adanya pendaftaran ini maka akan tercatat mengenai siapa pemilik, hak apa yang melekat dan segala perubahan keadaan tanah tersebut juga akan terekam.

\section{Pembebanan Jaminan Fidusia}

Hubungan hukum antara pemberi fidusia (debitor) dan penerima fidusia (kreditor) merupakan hubungan yang didasarkan pada kepercayaan, hal ini sesuai makna dasar dari fidusia yaitu kepercayaan. Pihak pemberi fidusia memiliki rasa percaya bahwa pihak penerima fidusia akan mengembalikan hak kepemilikan benda yang telah diserahkan setelah diselesaikan kreditnya. Begitu pula pihak penerima fidusia akan percaya bahwa pihak pemberi fidusia tidak ada niat akan menyalahgunakan benda jaminan yang dikuasinnya. ${ }^{13}$

Secara umum tahapan jaminan fidusia terdiri dari dua tahap penting, yaitu tahap pembebanan jaminan fidusia yang

${ }^{13}$ Gunawan widjaja, Ahmad Yani, Jaminan Fidusia, Jakarta : Rajagrafindo Persada, 2000), 119 
dibuat secara notarial dan tahap pendaftaran jaminan fidusia ke kantor pendaftaran fidusia.

Berdasarkan ketentuan Pasal 5 ayat (1) UUJF menyatakan bahwa pembebanan benda dengan jaminan fidusia dibuat dengan syarat-syarat: akta notaris, dalam bahasa Indonesia, dan merupakan Akta Jaminan Fidusia. Halhal yang termuat dalam akta jaminan fidusia sekurangkurangnya memuat keterangan-keterangan sebagai berikut: ${ }^{14}$ identitas pihak pemberi dan penerima fidusia; data perjanjian pokok yang dijamin fidusia; uraian mengenai benda yang menjadi objek jaminan fidusia; nilai penjaminan; dan nilai benda yang menjadi objek jaminan fidusia.

Keharusan pembuatan akta jaminan fidusia dengan akta otentik atau akta notarial berkaitan dengan persoalan alat bukti dan proses pembuktian. Akta berfungsi secara formil dalam arti bahwa untuk lengkapnya atau sempurnanya suatu perbuatan hukum, dan berfungsi sebagai alat bukti. Akta otentik adalah akta yang dibuat oleh pejabat yang diberi wewenang untuk itu oleh penguasa menurut ketentuanketentuan yang telah ditaetapkan, baik dengan atau tanpa bantuan dari yang berkepentingan, yang mencatat apa yang dimintakan untuk dimuat didalamnya oleh yang berkepentingan. Akta otentik terutama memuat keterangan

\footnotetext{
${ }^{14}$ Pasal 6 UUJF.
} 
seorang pejabat yang menerangkan apa yang dilakukannya atau dilihat dihadapannya. ${ }^{15}$

Mengenai keabsahan dari Akta Jaminan Fidusia baik yang dibuat dengan akta otentik maupun akta dibawah tangan, sama-sama memiliki kekuatan pembuktian, selama dibuat sesuai dengan ketentuan dan syarat-syaratnya. Jaminan Fidusia dapat dikatakan sah apabila didahului dengan terpenuhinya syarat-syarat sahnya perjanjian dan selanjutnya diikuti proses pembebanan benda jaminan yang dibuat menggunakan akta notaris. ${ }^{16}$

Permasalahan yang timbul bukan hanya mengenai keabsahan dari akta jaminan fidusia tersebut, melainkan bahwa terhadap pembuatan akta jaminan fidusia yang dibuat dengan akta notaris dikenakan biaya. Hal ini dinyatakan didalam pasal 5 ayat (2) UU Jaminan Fidusia: “Terhadap pembuatan akta jaminan fidusia sebagaimana dimaksud dalam ayat (1), dikenakan biaya yang besarnya diatur lebih lanjut dengan Peraturan Pemerintah.

Demikian juga dalam PP No. 86 tahun 2000 tentang Tata cara Pendaftaran Jaminan Fidusia dan Biaya Pembuatan Akta Jaminan Fidusia, dalam hal permohonan pendaftaran jaminan fidusia, mensyaratkan adanya salinan akta notaris

\footnotetext{
${ }^{15}$ Sudikno Mertokusumo, Hukum Acara Perdata Indonesia, (Yogyakarta : Liberty, 1985), 124

${ }^{16}$ Putu Evi Komala Dewi, Kepastian Hukum Bagi Kreditur Dalam Sistem Pendaftaran Jaminan Fidusia Secara Elektronik, Jurnal Kertha Wicaksana Vol. 1 No. 2 2017, https://fh-warmadewa.ac.id/e-jurnal/index.php/law/article/view/49
} 
tentang pembebanan Jaminan fidusia. Pembuatan akta jaminan fidusia dengan akta notaris juga berkaitan dengan adanya pengenaan biaya dalam pembuatan akta tersebut dan merupakan salah satu persyaratan pendaftaran akta jaminan fidusia pada kantor pendaftaran fidusia. Yang dari pendaftaran tersebut akan diperoleh Sertifikat Jaminan Fidusia.

\section{Pendaftaran Jaminan Fidusia}

Tahapan selanjutnya setelah proses pembuatan akta jaminan fidusia adalah pendaftaran jaminan fidusia kepada kantor pendaftaran fidusia untuk memperoleh sertifikat jaminan fidusia. Permohonan pendaftaran dilakukan oleh pihak penerima fidusia, kuasa atau wakilnya dengan melampirkan pernyataan pendaftaran jaminan fidusia, yang memuat: identitas pihak pemberi dan penerima fidusia; tanggal, nomor akta jaminan fidusia, nama, dan tempat kedudukan notaries yang membuat akta jaminan fidusia; Data perjanjian pokok yang dijamin fidusia; Uraian mengenai benda yang menjadi objek jaminan fidusia; Nilai penjaminan dan Nilai benda yang menjadi objek jaminan fidusia. Selanjutnya Kantor Pendaftara Fidusia mencatat Jaminan Fidusia dalam buku daftar fidusia pada tanggal yang sama dengan tanggal penerimaan permohonan pendaftaran. Dengan adanya pendaftaran ini, segala keterangan mengenai 
benda yang menjadi objek jaminan fidusia yang ada pada kantor pendaftaran fidusia terbuka untuk umum. ${ }^{17}$

Pendaftaran jaminan fidusia ini diperlukan untuk memberikan adanya kepastian hukum kepada para pihak berkepentingan, ${ }^{18}$ memberikan kepada penerima fidusia hak yang didahulukan (preferen) atas pelunasan hutangnya serta untuk memberi jaminan untuk penerima fidusia dan pihakpihak lain yang memiliki kepentingan atas benda tersebut. Pendaftaran juga bertujuan untuk memberikan perlindungan hukum kepada pihak kreditor (penerima fidusia) serta pihakpihak ketiga lainnya. ${ }^{19}$

Sebagai upaya atau perwujudan pemberian kepastian hukum tersebut, kewajiban untuk melakukan pendaftaran jaminan fidusia juga sebagai bentuk pemenuhan dari publisitas dalam hukum jaminan. Oleh karenanya permohonan pendaftaran jaminan fidusia merupakan syarat mutlak untuk memperoleh Sertifikat Jaminan Fidusia dari kantor pendaftaran fidusia.

Pada saat pembuatan akta jaminan fidusia yang dibuat dengan akta notaris, saat itu eksistensi Jaminan fidusia belum

\footnotetext{
${ }^{17}$ Pasal 18 UU Jaminan Fidusia

${ }^{18}$ Indah Junyanitha, Ni Wayan; Mudana, I Nyoman; Sukihana, Ida Ayu. Pendaftaran Fidusia Dalam Praktek Pemberian Kredit Pada PT. Bank Perkreditan Rakyat Raga Jayatama Di Batubulan Gianyar, Kertha Semaya: Journal Ilmu Hukum, [S.l.], v. 4, n. 2, sep. 2015. ISSN 2303-0569. Available at: <https://ojs.unud.ac.id/index.php/kerthasemaya/article/view/15341>.

${ }^{19}$ Hari Julio, Akibat Hukum Terhadap Objek Jaminan Fidusia Atas Keterlambatan Pendaftaran Pada Kantor Pendaftaran Fidusia, https://jurnal.usu.ac.id/index.php/premise/article/viewFile/18620/7904
} 
ada atau belum lahir. Jaminan fidusia tersebut baru terlahir bersamaan dengan saat tanggal dicatatnya akta jaminan fidusia dalam Buku Daftar Fidusia. Lahirnya hak yang didahulukan (preferen) dihitung sejak tanggal yang sama dengan tanggal pendaftaran obyek Jaminan Fidusia di Kantor Pendaftaran Fidusia. $^{20}$ Pada saat itulah kedudukan yang diutamakan dari penerima fidusia muncul terhadap kreditorkreditor lain muncul terhadap objek jaminan yang sama.

Ketentuan yang mengatur tentang kewajiban untuk melakukan pendaftaran Jaminan Fidusia merupakan suatu terobosan yang dinilai sangat penting, hal ini mengingat karena pada umumnya yang menjadi objek dari jaminan fidusia adalah objek benda-benda yang bergerak. Sehingga akan mengalami kesulitan untuk mengetahui siapa sebenarnya yang menjadi pemiliknya. Terobosan demikian ini menjadi lebih bermakna lagi apabila dikaitkan dengan adanya aturan Pasal 1977 KUHPerdata yang secara tegas menyatakan: barang siapa yang menguasai benda bergerak maka ia akan dianggap sebagai pemiliknya (bezit geldt als volkomen titel). ${ }^{21}$

Terhadap pengajuan permohonan pendaftaran jaminan fidusia diatas, kantor yang bertugas menerima pendaftaran fidusia akan menerbitkan Sertifikat Jaminan Fidusia yang pada prinsipnya merupakan salinan Buku Daftar Fidusia dan

\footnotetext{
${ }^{20}$ M. Yasir, Aspek Hukum Jaminan Fidusia, SALAM; Jurnal Sosial \& Budaya Syar-i FSH UIN Syarif Hidayatullah Jakarta Vol. 3 No. 1 (2016), pp.75-92, http://journal.uinjkt.ac.id/index.php/salam/article/download/3307/pdf

${ }^{21}$ Gunawan widjaja, Ahmad Yani, Jaminan Fidusia, 148
} 
menyerahkan kepada penerima fidusia. Didalam sertifikat jaminan fidusia yang diserahkan tersebut tercantum kata-kata atau irah-irah "Demi Keadilan Berdasarkan Ketuhanan Yang Maha Esa”. Sertifikat jaminan fidusia memiliki kekuatan eksekutorial yang sama dengan putusan pengadilan yang sudah in kracht van gewijsde atau berkekuatan hukum tetap. Sertipikat Jaminan Fidusia tersebut dapat digunakan untuk melakukan eksekusi objek jaminan jika debitor wanprestasi tanpa perluk melakukan proses persidangan di pengadilan. ${ }^{22}$ Selanjutnya jika pihak debitor atau pemberi fidusia cidera janji, maka pihak penerima fidusia memiliki hak untuk melelang atau menjual benda objek jaminan fidusia atas kekuasaan kreditor sendiri. perwujudan dari perbuatan cidera janji dari debitor tersebut dapat dalam bentuk perbuatan yang sama sekali tidak melaksanakan prestasi, keliru dalam menunaikan prestasi atau dalam bentuk debitor terlambat memenuhi prestasi. ${ }^{23}$

Berdasarkan uraian diatas telah jelas bahwa eksistensi atau kelahiran jaminan fidusia adalah ketika akta jaminan fidusia telah didaftarkan dan dicatat dalam buku daftar fidusia pada kantor pendaftaran fidusia. Dengan demikian, secara a contrario, maka jika akta jaminan fidusia yang telah

\footnotetext{
${ }^{22}$ Retno Puspo Dewi, Nor Saptanti, Hari Purwadi, Kekuatan Eksekutorial Sertifikat Jaminan Fidusia Berdasar Undang Undang Nomor 42 Tahun 1999 Tentang Jaminan Fidusia, Jurnal Repertorium Volume IV No. 1 Januari-Juni 2017, https://media.neliti.com/media/publications/213284-kekuatan-eksekutorial-sertifikatjaminan.pdf;

${ }^{23}$ J. Satrio, Hukum Perikatan-Perikatan Pada Umumnya, (Bandung : Alumni, 1999), 122
} 
dibuat secara noariil tidak didaftarkan ke kantor pendaftaran fidusia, maka kreditor (penerima fidusia) tidak akan memperoleh sertifikat jaminan fidusia. Oleh karena itu akta jaminan fidusia yang sudah dibuat tersebut tidak dapat memenuhi asas publisitas dalam hukum jaminan fidusia.

\section{Kewajiban Pendaftaran Jaminan Fidusia}

Sebelum lahirnya UUJF, persoalan pendaftaran jaminan fidusia bukanlah suatu kewajiban, namun dengan lahirnya UUJF, pendaftaran jaminan fidusia merupakan tahapan yang sangat krusial. ${ }^{24}$ Hal inipun dijumpai dalam Penjelasan Umum bahwa salah satu sebab jaminan fidusia tidak memberikan kepastian hukum terutama kepada penerima fidusia salah satunya adalah karena jaminan fidusia tersebut tidak didaftarkan. ${ }^{25}$

Pemenuhan terhadap asas publisitas didalam jaminan fidusia dapat ditemukan dalam ketentuan yang mewajibkannya pendaftaran jaminan fidusia sebagaimana dinyatakan Pasal 11 ayat (1) UUJF yaitu benda jaminan fidusia wajib didaftarkan. Selanjutnya dalam ayat (2) disebutkan bahwa kewajiban pendaftaran tetap berlaku meskipun benda tersebut berada diluar wilayah NKRI. Jika dicermati lebih mendalam bahwa rumusan pasal 11 ayat (1) menunjukkan bahwa sebenarnya yang diwajibkan untuk didaftarkan itu adalah bendanya dan bukan jaminannya. Namun demiki

\footnotetext{
${ }^{24}$ Tan Kamelo, Hukum Jaminan Fidusia Suatu Kebutuhan yang Didambakan, 213

${ }^{25}$ Penjelasan Umum UUJF, angka 3.
} 
ketentuan pasal-pasal lain yang mengatur tentang pendaftaran, ditemukan bahwa kewajiban pendaftaran ditujukan pada jaminannya. Seperti ditemukan Pasal 12 ayat (1) yang menyatakan pendaftaran dilakukan di Kantor Pendaftaran Fidusia. Ketentuan pasal 12 ayat (1) menyebutkan yang didaftarkan adalah jaminan fidusia, artinya yang didaftarkan sebenarnya adalah akta jaminan fidusia. Adanya penggunaan istilah dalam ketentuan pasal-pasal yang mengatur tentang pendaftaran ini telah menimbulkan berbagai penafsiran terkait apa sebenarnya yang wajib untuk didaftarkan itu, apakah benda yang dibebani jaminan fidusia ataukah akta jaminan fidusia.

Memang harus diakui bahwa berdasarkan ketentuan yang tertuang dalam pasal-pasal UUPK, tidak terdapat satu pasalpun yang secara tegas menyatakan bahwa terhadap jaminan fidusia yang tidak dilakukan pendaftaran menjadi tidak sah. ${ }^{26}$ Dengan demikian ketentuan tetang kewajiban pendaftaran diatas hendaknya diapahami bahwa untuk keberlakuan ketentuan-ketentuan yang terdapat didalam UUJF maka syarat yang wajib dipenuhi salah satunya adalah pendaftaran jaminan fidusia. Hal ini dimaksudkan agar berbagai keunggulan dan hak-hak yang diberikan kepada pihak penerima fidusia dapat dinikmati, salah satu contohnya

\footnotetext{
${ }^{26}$ Muhammad Hilmi Akhsin, Akibat Hukum Jaminan Fidusia Yang Tidak Didaftarkan Menurut UU Nomor 42 Tahun 1999, Jurnal Akta Vol. 4 No. 3 September 2017, http://jurnal.unissula.ac.id/index.php/akta/article/download/1825/1374
} 
adalah jaminan tersebut tidak memiliki kekuatan untuk melakukan eksekusi. ${ }^{27}$

Perihal kewajiban pendaftaran jaminan fidusia ini dapat dianalisis dalam dua perspektif, yaitu menggunakan perspektif penormaan dan perspektif asas hukum benda yang dianut dalam KUHPerdata. Untuk yang pertama akan diuraikan terlebih dahulu terkait dengan penormaan tentang kewajiban pendaftaran jaminan fidusia.

Menurut Hans Kelsen, bahwa makna hukum yang khas dari tindakan pada dasarnya bersumber dari norma yang isinya mengacu pada tindakan itu, sehingga ia dapat ditafsirkan sesuai dengan norma tersebut. Fungsi norma menurutnya adalah sebagai skema daripada penafsiran. Berdasarkan pemahaman itu, maka pertimbanganpertimbangan bahwa sebuah perbuatan dari perilaku seseorang yang dilakukan pada satu waktu dan tempat tertentu, yakni perbuatan yang legal atau illegal merupakan satu penafsiran dari norma yang khusus. Sehingga sebuah norma ditafsirkan sebagai sesuatu hal yang semestinya ada atau semestinya terjadi. ${ }^{28}$

Suatu kaidah norma termasuk dalam suatu sistim norma tertentu hanya bisa diuji dengan cara

\footnotetext{
${ }^{27}$ Nur Hayati, Aspek Hukum Pendaftaran Jaminan Fidusia Berdasarkan Undang-Undang Nomor 42 Tahun 1999 Tentang Jaminan Fidusia, Lex Jurnalica (Journal of Law), Vol 13 no. 2 2016, https://ejurnal.esaunggul.ac.id/index.php/Lex/issue/view/272

${ }^{28}$ Hans Kelsen, dikutip dari Andi Prajitno, Hukum Fidusia, (Malang : Bayumedia, 2011), 151
} 
mengonfirmasikan norma tersebut medapatkan validitasnya dari norma yang bersifat dasar yang membentuk susunan norma tersebut. Proses pencarian terhadap alasan validitas suatu norma tertentu, seperti halnya dengan pencarian suatu sebab akibat, bukanlah merupakan suatu regressus ad infinitum, suatu proses yang tanpa akhir, namun proses tersebut berakhir dengan telah ditemukannya satu norma tertinggi yang dijadikan dasar dari validitas terakhir dalam suatu sistem norma. ${ }^{29}$

Suatu peraturan hukum sebenarnya terdiri dari beberapa norma yang mengatur tentang perilaku manusia didalam interaksi sosial dengan lingkungan sekitarnya. Menurut Hart, setidaknya terdapat 3 (tiga) karakteristik suatu hukum atau sistem hukum, yakni validity, efficacy, acceptance. ${ }^{30}$ Sebuah ketentuan hukum dinilai memiliki validity, bila dapat dilacak dan ditelusuri secara formal, sesuai prosedur sistem pembuatan maupun perubahan suatu peraturan hukum. Sebuah sistem hukum dapat dinyatakan mempunyai efficacy, jika sebuah ketentuan hukum itu ditaati dan dipatuhi oleh anggota masyarakat pada umumnya. Sedangkan untuk acceptance dapat diartikan sebagai suatu keadaan dapat diterimanya aturan hukum tertentu oleh anggota masyarakat sebagai suatu aturan yang dinilai valid.

\footnotetext{
${ }^{29}$ Hans Kelsen, dikutip dari Andi Prajitno, Hukum Fidusia, 151

${ }^{30}$ Peter Mahmud Marzuki, Pengantar Ilmu Hukum, (Jakarta : Prenada Media, 2009), 69
} 
Menurut Hart, aturan hukum terdiri dari aturan yang dinamakan sebagai primary rules dan atauran sebagai secondary rules..$^{31}$ Kelompok primary rules merupakan aturanaturan yang memberikan suatu hak dan sekaligus membebankan kewajiban tertentu kepada masyarakat. Contoh yang dapat dikemukakan terkait primary rules adalah aturan yang terdapat dalam hukum pidana, yaitu aturan yang melarang seseorang melakukan perbuatan pembunuhan, penganiayaan, pencurian dan lainnya. Sedangkan aturan secondary rules merupakan aturan-aturan tertentu yang bersifat menetapkan bagaimana caranya dan oleh siapa aturan primary rules tersebut dibuat, aturan dinyatakan berlaku atau diubah, dan juga suatu aturan dinyatakan tidak lagi berlaku. Contoh lain yang tergolong kedalam kelompok secondary rules adalah aturan yang mengatur pembentukan kontrak serta berbagai aturan dalam bidang hukum perdata yang mengatur bagaimana terjadinya kewajiban hukum tertentu.

Terkait primary rules ini, Bruggink menyatakan bahwa tampilan suatu norma itu dapat dilihat dalam berbagai bentuk, antara lain :32 pertama, dalam bentuk Perintah (gebod), yaitu membebankan kewajiban untuk melakukan sesuatu; kedua, Larangan (verbod), yang merupakan kewajiban untuk tidak melakukan sesuatu; ketiga,

\footnotetext{
${ }^{31}$ Peter Mahmud Marzuki, Pengantar Ilmu Hukum, 66

${ }^{32}$ Johny Ibrahim, Teori \& Metodologi Penelitian Hukum Normatif, (Malang : Bayumedia, 2011), 53
} 
Pembebasan (vrijstelling, dispensasi), yang merupakan pembolehan (verlof) secara khusus untuk tidak melakukan suatu perbuatan tertentu yang secara umum diwajibkan; dan keempat, Izin (toestemming, permisi), adalah pembolehan yang diberikan secara khusus untuk melakukan perbuatan yang secara umum tidak boleh dilakukan atau dilarang.

Sebuah aturan hukum dilihat dari daya kerjanya, dapat dibedakan menjadi dua kelompok, yakni hukum yang bersifat memaksa (dwingend recht) dan yang mengatur (aanvullend recht). Perlu dipahami bahwa pengertian kata memaksa ditujukan bahwa pembuat hukum tidak memberi kebebasan untuk melaksanakan atau tidak melaksanakan aturan hukum itu. Aturan hukum yang dibuat haruslah ditaati denga napa adanya dan tidak diberi pilihan apalagi disimpangi oleh orang yang mempunyai suatu hubungan hukum. Sedangkan untuk aturan hukum yang mengatur (aanvullend recht) adalah suatu aturan hukum akan menjadi acuan apabila pihak-pihak tidak merumuskan sendiri tentang aturan-aturan yang disepakati berlaku untuk hubungan hukum diatara mereka. Aturan hukum demikian ini dapat memberikan disposisi tertentu serta untuk mengisi kekosongan aturan untuk hal-hal yang tidak diatur oleh para pihak sendiri.

Sebuah aturan hukum dapat dikatakan bersifat memaksa apabila memiliki ciri-ciri antara lain:33 pertama,

\footnotetext{
${ }^{33}$ Johny Ibrahim, Teori \& Metodologi Penelitian Hukum Normatif, 240
} 
digunakan kata "wajib", kedua, menyangkut kepentingan umum atau ketertiban umum. Ciri lain terkait norma yang bersifat memaksa ini, menurut C. Asser, ${ }^{34}$ terdapatnya perintah yang rangkap, yang terdiri satu perintah ditujukan untuk individu yang tunduk aturan hukum, satu perintah lagi ditujukan kepada perlengkapan Negara yang dibebani dengan penegakan undang-undang tersebut. Sedangkan pada hukum yang bersifat pelengkap hanya terdapat perintah yang kedua yaitu perintah kepada perlengkapan Negara yang dibebani penegakan suatu undang-undang, tetapi kepada individu tidak diberikan suatu perintah tertentu.

Norma pendaftaran jaminan fidusia yang tertuang dalam Pasal 11 ayat (1) UUJF menyatakan bahwa pendaftaran fidusia adalah wajib dilakukan. Penggunaan kata "wajib" dalam pasal ini menunjukkan bahwa aturan tersebut sebagai sesuatu yang mesti dilakukan dan saat yang sama tidak boleh untuk ditinggalkan. Pihak-pihak yang diperintahkan untuk melakukan suatu perbuatan tidak mempunyai pilihan lain selain untuk melakukan apa yang diperintahkan untuk dilaksanakanny. Adanya kewajiban untuk melaksanakan norma tertentu yang diperintahkan, adalah ciri dari norma yang memiliki sifat memaksa sebagaimana telah diuraikan diatas.Sifat norma tentang pendaftaran jaminan fidusia dalam

\footnotetext{
34 Paul Scholten, Mr. Asser Penuntun Dalam Mempelajari Hukum Perdata Belanda, Diterjemahkan oleh Siti Sumarti Hartono, (Yogyakarta : Gadjah Mada University Press, 1992), 28-29
} 
Pasal 11 ayat (1) UUJF adalah suatu norma hukum yang bersifat memaksa (dwingend recht) dan bukan bersifat mengatur (aanvullend recht) ini dapat ditinjau dari hukum benda pada asasnya menganut sistem tertutup. Sesuai dengan sistematika dalam Kitab Undang-Undang Hukum Perdata (KUHPerdata), maka hukum jaminan yang dilekati dengan sifat kebendaan merupakan bagian dari hukum benda. Berdasarkan sifatnya, hukum benda sebagaimana diatur dalam Buku II KUH Perdata adalah bersifat tertutup. ${ }^{35}$ Bersifat tertutup ini dimaksudkan bahwa aturan hukum yang berlaku dalam hukum benda hanyalah hak-hak kebendaan yang sudah ditetapkan secara tegas didalam aturan undangundang. Masyarakat atau para pihak tunduk pada aturan undang-undang tersebut dan tidak dimungkinkan untuk membuat aturan lain diluar dari apa-apa yang sudah dinyatakan dalam undang-undang. Aturan yang mengatur mengenai hak-hak jaminan kebendaan merupakan bagian dari hukum benda, oleh karenanya maka ketentuanketentuan yang ada didalam hukum jaminan kebendaan lebih banyak dipengaruhi oleh ketentuan yang ada dalam hukum benda tersebut.

Sebagaimana diuraikan diatas bahwa hukum benda pada asasnya menganut sistem tertutup maka aturan-aturan yang ada dalam hukum jaminan fidusia sebagaimana tertuang

35 Moch. Isnaeni, Hipotek Pesawat Udara di Indonesia, (Surabaya : CV. Dharma Muda, 1996), 17 
dalam UUJF juga bersifat tertutup, artinya bahwa norma yang berlaku adalah norma yang telah ditetapkan dalam UUJF. Dengan kata lain, norma yang mengatur tentang pendaftaran jaminan fidusia sebagaimana tertadapat dalam UUJF adalah norma yang bersifat memaksa ( $d$ wingend recht).

Namun demikian didalam UUJF juga tidak memuat ketentuan apapun yang mengatur tentang akibat hukum yang akan ditanggung maupun aturan mengenai sanksi tertentu bila jaminan fidusia itu tidak didaftarkan. Hal ini jika dikaitkan dengan aturan pendaftaran yang bersifat $d w i n g e n d$ recht sebagaimana diatur Pasal 11 ayat (1) UUJF yang mewajibkan untuk melakukan pendaftaran jaminan fidusia. Dengan tidak adanya aturan tertentu mengenai sanksi apapu jika jaminan fidusia tersebut tidak didaftarkan, maka akan berakibat pada penggunaan kata "wajib” yang terdapat dalam Pasal 11 ayat (1) UUJF menjadi tidak mempunyai kekuatan mengikat terhadap pihak-pihak yang diberi kewajiban untuk melaksanakan pendaftaran jaminan. Hal ini karena pihalpihak yang diberi kewajiban untuk melaksanakan pendaftaran jaminan fidusia masih memiliki pilihan lain untuk melakukan pendaftaran atau untuk tidak melakukan pendaftaran. Namun demikian, sebagai sebuah konsekuensi dari tidak dilakukannya pendaftaran, maka secara hukum hak-hak derta keuntungan-keuntungan yang akan diberikan undang-undang kepada pihak penerima fidusia menjadi tidak diperoleh. 
Pada dasarnya, adanya kewajiban untuk melakukan pendaftaran jaminan itu bertujuan untuk memberikan perlindungan hukum dan hak dari pihak-pihak yang melakukan perbuatan hukum terhadap kemungkinankemungkinan terjadinya pelanggaran hak-hak mereka yang dilakukan oleh pihak ketiga. Secara tegas dinyatakan bahwa tujuan dari proses pendaftaran jaminan fidusia adalah dalam rangka memberikan kepastian hukum untuk pihak-pihak yang memiliki kepentingan dan preferen kepada penerima fidusia $^{36}$ serta untuk sebagai pemenuhan asas publisitas. ${ }^{37}$ Pendaftaran jaminan fidusia yang diatur Pasal 11 sampai 18 UUJF dibebankan kepada pihak penerima fidusia (kreditor), hal ini dimaksudkan agar perlindungan hukum dapat diberikan kepada penerima fidusia yang telah mengucurkan pinjaman kepada debitur untuk memastikan bahwa pinjaman yang sudah dikucurkan tersebut dapat dilunasi sesuai dengan perjanjian yang disepakati. Dengan demikian jika penerima fidusia (kreditor) tidak melakukan pendaftaran, maka kreditor tersebut tidak menikmati perlindungan dan keuntungan yang pada awalnya akan diberikan oleh UUJF.

Dalam jaminan fidusia, tahap pendaftaran adalah momentum yang penting sekali dan sangat krusial terutama didalam hal adanya kepastian hukum dan perlindungan untuk pihak kreditor. Hal ini disebabkan oleh karena hak

\footnotetext{
${ }^{36}$ Penjelasan Umum UUJF angka 3

37 Penjelasan Pasal 11 UUJF
} 
kebendaan atas jaminan fidusia tersebut baru lahir saat akta jaminan fidusia dicatat didalam Buku Daftar Fidusia ketika didaftarkan di Kantor Pendaftaran Fidusia. Selain untuk memperoleh adanya kepastian hokum, tujuan pendaftaran jaminan juga untuk melahirkan hak kebendaan. Sebelum dilakukan pendaftaran jaminan, maka hak yang dimiliki oleh pihak kreditur merupakan hak perseorangan yang bersifat relatif.

Dengan demikian apabila jaminan fidusia tidak didaftarkan maka kreditor tidak memperoleh hak-hak serta keuntungan-keuntungan yang sudah ditentukan dalam UUJF, antara lain: Hak kebendaan, hak yang didahulukan, hak eksekutorial, dan penerapan ketentuan pidana.

Hak kebendaan Jaminan fidusia akan lahir apabila jaminan tersebut didaftarkan, sebaliknya jaminan yang tidak didaftarkan tidak akan melahirkan kebendaan. Hak-hak yang lahir dari perjanjian tersebut adalah hak perseorangan yang bersifat obligatoir. Hak perorangan yang bersumber dari perjanjian obligatoir belum berubah menjadi hak kebendaan, selama perjanjian tersebut belum didaftarakan, sehingga sifatsifat yang melekat dalam hak tersebut adalah sifat-sifat sebagaimana yang terdapat dalam hak perorangan, yaitu bersifat relatif dalam arti hak tersebut hanya dapat dipertahankan terhadap orang tertentu saja. 
Hak untuk didahulukan (prefer) seperti diatur dalam Pasal 27 UUJF merupakan hak yang dipunyai oleh kreditor penerima fidusia untuk mengambil pelunasan piutangnya atas hasil eksekusi benda yang menjadi obyek jaminan fidusia. Kreditor sebagai pemegang sertifikat jaminan fidusia memiliki hak didahulukan dalam mengambil pelunasan piutangnya karena kedudukannya sebagai kreditor preferen. Hak yang didahulukan sebagai pemegang sertifikat jaminan Fidusia tidak menjadi hapus walaupun adanya kepailitan atau likuidasi yang dialami pihak Pemberi Fidusia. Kedudukan sebagai kreditor preferen tidak dapat dimiliki apabila jaminan fidusia tersebut tidak didaftarkan.

Demikian pula apabila debitor mengalami cidera janji, berdasarkan sertifikat jaminan fidusia, penerima fidusia memiliki hak untuk menjual objek jaminan fidusia atas kekuasaannya sendiri. Hal ini karena sertifikat jaminan fidusia memiliki kekuatan eksekutorial yang sama dengan putusan pengadilan yang telah memperoleh kekuatan hukum tetap, maka kreditor pemegang sertifikat jaminan fidusia tidak perlu mengajukan gugatan ke pengadilan apabila debitor cidera janji. Jaminan fidusia yang tidak didaftarkan, tidak dapat memiliki hak eksekutorial, sehingga apabila debitor cedera janji, maka untuk menuntut pengembalian piutangnya kepada debitor, kreditor harus melakukan gugatan kepada pengadilan negeri. 
Ketentuan pidana seperti diatur dalam pasal 35 dan 36 UUJF berlaku ketika tahapan-tahapan jaminan fidusia mengikuti ketentuan sebagaimana diatur dalam UUJF, salah satunya adalah bahwa jaminan fidusia wajib didaftarkan. apabila jaminan fidusia tidak didaftarkan, maka ketika terjadi perbuatan pidana yang diatur Pasal 35 UUJF berupa perbuatan sengaja memalsukan, mengubah, menghilangkan atau dengan cara apapun memberikan keterangan secara menyesatkan, serta Pasal 36 UUJF dalam hal perbuatan mengalihkan, menggadaikan, atau menyewakan Benda yang menjadi objek Jaminan Fidusia yang dilakukan tanpa persetujuan tertulis terlebih dahulu dari Penerima Fidusia, maka tidak dapat diancam dengan Pasal 35 dan Pasal 36 UUJF tersebut, tetapi diancam dengan ketentuan pidana sebagaimana diatur dalam Kitab Undang-Undang Hukum Pidana (KUHP).

\section{Kesimpulan}

Pemenuhan asas publisitas dalam jaminan fidusia dilakukan melalui pendaftaran jaminan fidusia ke Kantor Pendaftaran Fidusia. Terhadap permohonan tersebut, kantor pendaftaran akan mencatat jaminan tersebut dalam Buku Daftar Fidusia dan akan menerbitkan Sertifikat Jaminan Fidusia yang mempunyai irah-irah Demi Keadilan Berdasarkan Ketuhanan Yang Maha Esa. 
Penormaan pendaftaran jaminan fidusia dalam UUJF merupakan norma hukum yang bersifat memaksa (dwingend recht). Hal ini dapat dilihat melalui dua aspek yaitu adanya penggunaan kata wajib dalam UUJF merupakan norma perintah, dan dari aspek asas hukum benda yang bersifat tertutup, sehingga norma tersebut tidak dapat disimpangi. Terhadap jaminan fidusia tidak didaftarkan maka kreditor sebagai pihak penerima fidusia tidak memperoleh hak-hak serta keuntungan-keuntungan yang sudah ditentukan dalam UUJF, antara lain: Hak kebendaan, hak yang didahulukan (preferen), hak eksekutorial, dan penerapan ketentuan pidana.

\section{Daftar Pustaka}

Hasan, Djuhaendah. Lembaga Jaminan Kebendaan bagi Tanah dan Benda lain yang Melekat pada Tanah dalam Konsepsi Penerapan Asas Pemisahan Horisontal. Bandung: PT Citra Aditya Bakti, 1996.

HS, Salim. Perkembangan Hukum Jaminan Di Indonesia. Jakarta : PT. Raja Grafindo Persada, 2004.

Ibrahim, Johny. Teori \& Metodologi Penelitian Hukum Normatif. Malang : Bayumedia, 2011.

Isnaeni, Moch., Hipotek Pesawat Udara di Indonesia, Surabaya : CV. Dharma Muda, 1996. 
Kamelo, Tan. Hukum Jaminan Fidusia Suatu Kebutuhan yang Didambakan. Bandung : Alumni, 2006.

Kelsen, Hans, dikutip dari Andi Prajitno. Hukum Fidusia. Malang : Bayumedia, 2011.

Marzuki, Peter Mahmud. Pengantar Ilmu Hukum. Jakarta : Prenada Media, 2009.

Mertokusumo, Sudikno. Hukum Acara Perdata Indonesia. Yogyakarta : Liberty, 1985.

Mulyadi, Kartini dan Gunawan Widjaja, Seri Hukum Harta Kekayaan- Kebendaan pada Umumnya. Jakarta : Prenada Media, 2003.

Poesoko, Herowati. Parate Executie Obyek Hak Tanggungan.

Yogyakarta : Laksbang, 2008.

Prajitno, Andi. Hukum Fidusia-Problematika Yuridis Pemberlakuan UU No. 42 Tahun 1999. Malang : Bayumedia, 2011.

Satrio, J. Hukum Perikatan-Perikatan Pada Umumnya. Bandung : Alumni, 1999.

Scholten, Paul, Mr. Asser Penuntun Dalam Mempelajari Hukum Perdata Belanda, Diterjemahkan oleh Siti Sumarti Hartono. Yogyakarta : Gadjah Mada University Press, 1992.

Sofwan, Sri Soedewi Maschoen. Hukum Jaminan Di Indonesia, Pokok-pokok Hukum Jaminan dan Jaminan Perorangan. Yogyakarta: Liberti, 1980, 
Widjaja, Gunawan, Ahmad Yani. Jaminan Fidusia. Jakarta : Rajagrafindo Persada, 2000.

Hari Julio, Akibat Hukum Terhadap Objek Jaminan Fidusia Atas Keterlambatan Pendaftaran Pada Kantor Pendaftaran Fidusia, https://jurnal.usu.ac.id/index.php/premise/article/view File/18620/7904

Indah Junyanitha, Ni Wayan; Mudana, I Nyoman; Sukihana, Ida Ayu. Pendaftaran Fidusia Dalam Praktek Pemberian Kredit Pada PT. Bank Perkreditan Rakyat Raga Jayatama Di Batubulan Gianyar. Kertha Semaya: Journal Ilmu Hukum, [S.1.], v. 4, n. 2, sep. 2015. ISSN 2303-0569. Available at: <https://ojs.unud.ac.id/index.php/kerthasemaya/article Liew/15341>.

M. Yasir, Aspek Hukum Jaminan Fidusia, SALAM; Jurnal Sosial \& Budaya Syar-i FSH UIN Syarif Hidayatullah Jakarta Vol. 3 No. 1 (2016), pp.75-92, http://journal.uinjkt.ac.id/index.php/salam/article/dow nload $/ 3307 / \mathrm{pdf}$

Muhammad Hilmi Akhsin, Akibat Hukum Jaminan Fidusia Yang Tidak Didaftarkan Menurut UU Nomor 42 Tahun 1999, Jurnal Akta Vol. 4 No. 3 September 2017, http://jurnal.unissula.ac.id/index.php/akta/article/dow nload/1825/1374 
Nur Hayati, Aspek Hukum Pendaftaran Jaminan Fidusia Berdasarkan Undang-Undang Nomor 42 Tahun 1999 Tentang Jaminan Fidusia, Lex Jurnalica (Journal of Law), $\begin{array}{lllll}\text { Vol } & 13 & \text { no. } & 2 & 2016 \text {, }\end{array}$ https://ejurnal.esaunggul.ac.id/index.php/Lex/issue/vie $\underline{w} / 272$

Putu Evi Komala Dewi, Kepastian Hukum Bagi Kreditur Dalam Sistem Pendaftaran Jaminan Fidusia Secara Elektronik, Jurnal Kertha Wicaksana Vol. 1 No. 2 2017, https://fh-warmadewa.ac.id/ejurnal/index.php/law/article/view/49

Retno Puspo Dewi, Nor Saptanti, Hari Purwadi, Kekuatan Eksekutorial Sertifikat Jaminan Fidusia Berdasar Undang Undang Nomor 42 Tahun 1999 Tentang Jaminan Fidusia, Jurnal Repertorium Volume IV No. 1 Januari-Juni 2017

https://media.neliti.com/media/publications/213284kekuatan-eksekutorial-sertifikat-jaminan.pdf 